\title{
\#RHODES MUST FALL: A POSTHUMANIST ORIENTATION TO DECOLONISING HIGHER EDUCATION INSTITUTIONS
}

\author{
K. Murris \\ School of Education \\ University of Cape Town \\ Cape Town, South Africa \\ e-mail: karin.murris@uct.ac.za
}

\section{ABSTRACT}

Critical posthumanism focuses on difference, rather than identity, and queers humanist philosophy that has its roots in western metaphysics, which has had a strong humanist articulation since Descartes. Humanism centres on the autonomous adult self as sole source of knowledge production, and instils binaries that marginalise, divide and dichotomise the 'other' in age, race, ethnicity, ability and sexuality. Postcolonial theorising interrogates these power-producing binaries, but tends to retain the dominant western ontological binary between language and reality, thereby assuming that knowledge production is always mediated through the discursive and represented in human-made languages, keeping the material world at a distance. The key question is 'What is left out, forgotten or ignored by using the discursive apparatus of the social sciences only?'.

Using Karen Barad's reading of quantum physics I propose a radically different and positive philosophical orientation towards decolonisation and a 'post'colonial future through a juxtaposition of a humanist and a posthumanist analysis of a series of photos I 'made' of the Cecil Rhodes's statue before it was removed from the University of Cape Town's campus. The question what it means to decolonise a university is not only epistemological, but also ontological and can remain radically open when we view meaning making as discursive and material, thereby doing justice to the agency of the nonhuman other.

Keywords: \#Rhodesmustfall, posthumanism, decolonising, higher education, postcolonial theory, diffractive methodology, nomadic citizenship, Barad, Cecil Rhodes statue

\section{THE SHADOW OF APARTHEID AND THE AFFIRMATIVE FORCE OF HUMAN EXCREMENT}

Motivated by the still visible signs of colonialism and lack of transformation at the historically white University of Cape Town (UCT), on 9 March 2015 black student Chumani Maxwele scooped human excrement from a portable flush toilet in the township of Khayelitsha and smeared it on the statue of British colonialist Cecil Rhodes - a powerful geo-political material and discursive action. The original location of the excrement is significant. Khayelitsha is a 
large suburb outside Cape Town and built in 1985 by the government to house - and sometimes forcefully relocate to - coloured and black people during apartheid. The majority of the black inhabitants live in shacks and share basic amenities, such as water, electricity and toilets. Although statue defaecement as a political action has a long history the focus of this article is not on a genealogy of such actions, but on a critical posthumanist analysis of this particular event and the important difference this orientation makes in terms of justice.

The shadow of apartheid and deep institutionalised racism and sexism continues to make people angry. For Chumani Maxwele it was unbearably humiliating to have to walk past a statue glorifying someone now regarded as a racist. The presence of such a statue on campus cast a shadow on black and other students alike (Figure 1), who object to, or who struggle to identify with, an institution that harbours a statue immortalising a British imperialist.

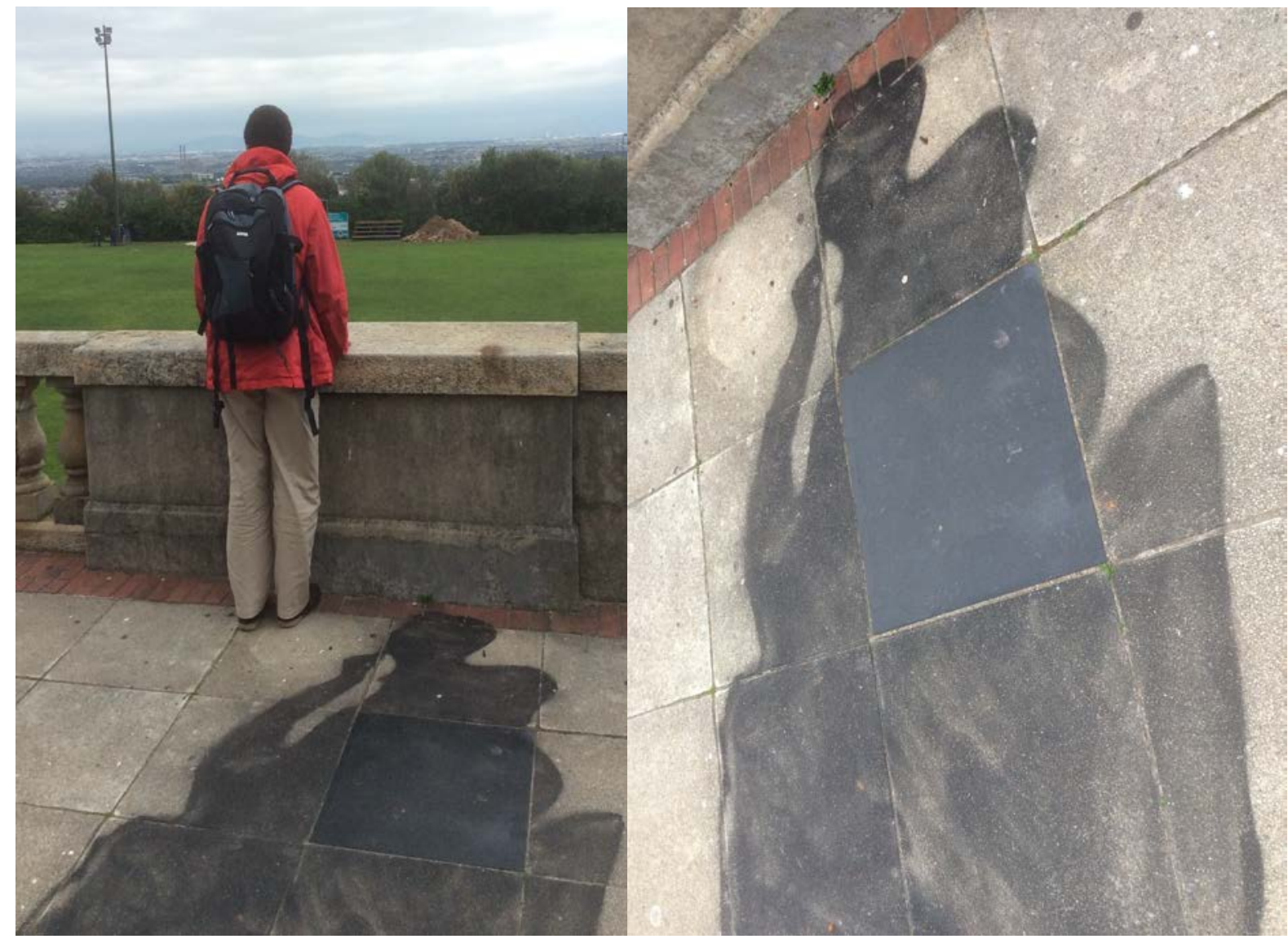

Figure 1: A painted shadow of the Rhodes statue

In many respects Rhodes is the archetypal subject of humanism: white, masculine, able-bodied and European (Braidotti 2013), though apparently not heterosexual. Critical posthumanist and feminist philosopher, Rosi Braidotti (2013) points out that this archetype of the 'human' is the yardstick against which humanism measures the worth of the 'other'. 
The 'incident' triggered further action, such as occupation of university buildings, as well as on-going debates and changes at UCT and other universities across South Africa and abroad (England, Scotland, US). The event started the \#Rhodesmustfall movement led by students and supported by many black and white staff members. Maxwele’s embodied action gave a dramatic urgency to post-apartheid transformation and the decolonisation of the university. The a/effect of this event has been profound and continues to ripple on, having already materialised \#Rhodesmustfall at Oxford and other universities as well as the \#Feesmustfall movement, which led to nationwide shut down of South African universities, postponement of end of year exams, changes to the nature of employment conditions at universities ('insourcing' instead of 'outsourcing') and no increase in tuition fees for all students in 2016. As political scientist and philosopher Achille Mbembe (2015) already described poignantly in September of 2015:

The winds blowing from our campuses can be felt afar, in a different idiom, in those territories of abandonment where the violence of poverty and demoralization having become the norm, many have nothing to lose and are now more than ever willing to risk a fight. They simply can no longer wait, having waited for too long now.

\#Rhodesmustfall has given urgency to the need to decolonise a higher education curriculum that centres on western epistemology and is built around the ideas of theorists from the global north and this includes the very notion of university education itself. At UCT the drop-out of black students is three times as high as that of white students, although drawing accurate conclusions about institutional exclusion from these facts is not straightforward. It does not necessarily follow from these figures that 'something institutional is hindering students from success' as Shannon Morreira $(2015,3)$ claims. Black students require substantially less average marks for their final high school exam to qualify for entry into university. Although this positive discrimination does not make up for the structural disadvantage that black students are victims of, it does make it more complicated to draw conclusions from drop-out rates. However, it is certainly the case that students from lower socioeconomic backgrounds are systematically disadvantaged (also educationally) from a very early age. Particularly in a country such as South Africa that struggles to provide a quality education for all (Fleisch 2008), with a deeply dividing private school system historically accessed by white learners only, structural educational inequality requires transformation that should start at birth (Van der Berg, Taylor, Gustafsson, Spaull and Armstrong 2011).

\section{COVERING UP}

Shortly after the statue's defecation, it was covered with black plastic and students were invited 
to post their comments (Figure 2).

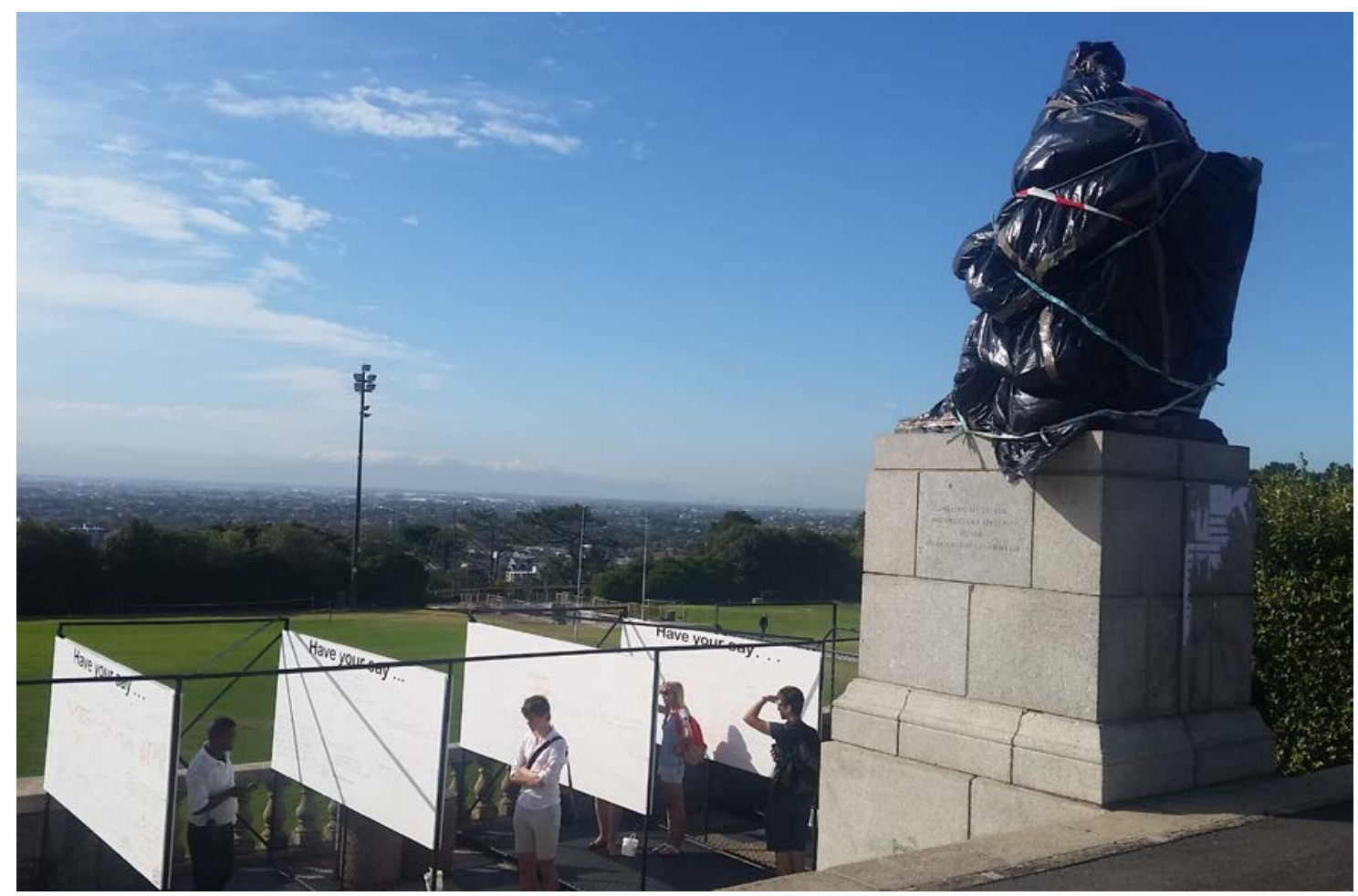

Figure 2: The Cecil Rhodes statue covered in black plastic. And students express their opinions

Some students used them to express very diverse opinions with strong disagreements (see e.g. Figure 4), and even insults. The boards were then removed and with it powerful pedagogical opportunities for public democratic engagement - covering up, one could argue, the deep differences that exist about \#Rhodesmustfall on campus at that moment in time. There is much anger about the fact that twenty-one years into democracy, the large majority of South Africans, who significantly are also black, live in poverty with no access to good quality education, safe and clean living conditions and easy access to properly paid jobs. So anger is growing - what Michalinos Zembylas $(2007,16)$ calls 'moral anger', which is desirable because it motivates people to oppose injustice. The politicisation of anger can be a critical and transformative force that helps to materialise better teaching and learning opportunities for marginalised students (Zembylas and Chubbuck 2009).

Exactly a month after the defecation, the bronze statue was removed from campus, and like the university it 'left behind', faced an uncertain and in/determinate future. Of course, the removal of the statue will not remove 'Rhodes' from the university - the shadow (Figure 1) is significant. He, his family and his legacy are completely entangled with UCT. As a mining magnate it was imperative for Rhodes and others to develop a high quality institution to educate scholars and engineers in minerology and geology to support the country's emerging diamond 
and gold-mining industries. As a result UCT was founded in 1829 as the South African College, a high school for boys. The entanglement with Rhodes is materialised in UCT as it is: its buildings, the people working there, the furniture, the students, and the traces are visible and affect those who pay attention.

These human and nonhuman materials are part of the world as real physical entities or beings, though not fixed or delineated, unlike the Kantian understanding of phenomenon. Phenomena for feminist philosopher and quantum physicist Karen Barad (2007, 128-129) are specific 'intra-actions' of human and nonhuman objects. The neologism expresses the profound idea that bodies are brought into existence ontologically through material and discursive relations, and not the other way round, as is the case with the humanist concept of 'interaction', which assumes that bodies exist independently and ontologically prior to their relationships with other bodies (Barad 2007; 2013, 815).

What we can learn from quantum physics is that intra-actions are indeterminate in both space and time. Barad $(2014,169)$ reminds us that in quantum physics each moment 'in’ time is 'an infinite multiplicity ... broken apart in different directions'. Importantly, what this means is not only that we do not know what will happen when bodies intra-act (which would be an epistemological issue), but it is unpredictable what will materialise, that is, brought into existence ontologically. When we analyse the defecation of the Rhodes statue at UCT as a phenomenon in the Baradian sense, it is imperative to move beyond the anthropocentric focus on the discursive only and to acknowledge the indeterminate agency of the relationship between the material world and the discursive. Barad calls her posthumanist framework 'agential realism' and explains how it makes us think radically different about concepts that assume binary thinking, such as causality, agency, power and identity - concepts core to 'post'colonial theorising:

[agential realism] provides an understanding of the role of the human and nonhuman, material and discursive, and natural and cultural factors in scientific and other social-material practices, thereby moving such considerations beyond the well-worn debates that pit constructivism against realism, agency against structure, and idealism against materialism. (Barad 2007, 26).

To illustrate how agential realism can make us think differently about the decolonisation of a university, I will focus in this article on a dis/continuous analysis of some photos I took of the statue around the time of its removal from campus. I will keep re-turning to them as my explanation of the 'new' onto-epistemology unfolds. These photos are infinitely rich, condensed nodes (Barad 2014, 169) - not 'slices' to be objectively examined. Like the 'post' in 'post'humanism, the philosophical orientation I draw on does not indicate a turning away 
from or a moving beyond humanism. Resonating with insights from quantum physics, for a critical posthumanist the past cannot be left behind, so the new is not a 'supercessionary break with the old ... but a matter of inheritance and indebtedness to the past as well as the present' (Barad in Juelskjaer and Schwennesen 2012, 13). Importantly, insights from quantum physics do not only hold for entities at micro level such as atoms, but also at macro level quantum physics calls into question the nature of oneness as well as twoness (Barad 2014, 178). Events, entities, even humans are quantum entanglements, not bounded objects 'in' space and time: 'Between will never be the same’' (Barad 2014, 178).

\section{THE RELATIONSHIP ‘BETWEEN’ TWO STATUES}

On the afternoon the Rhodes statue was removed, UCT fine arts student, Sethembile Msezane, became a statue by carefully balancing her body on a plinth for four hours (Figure 3).

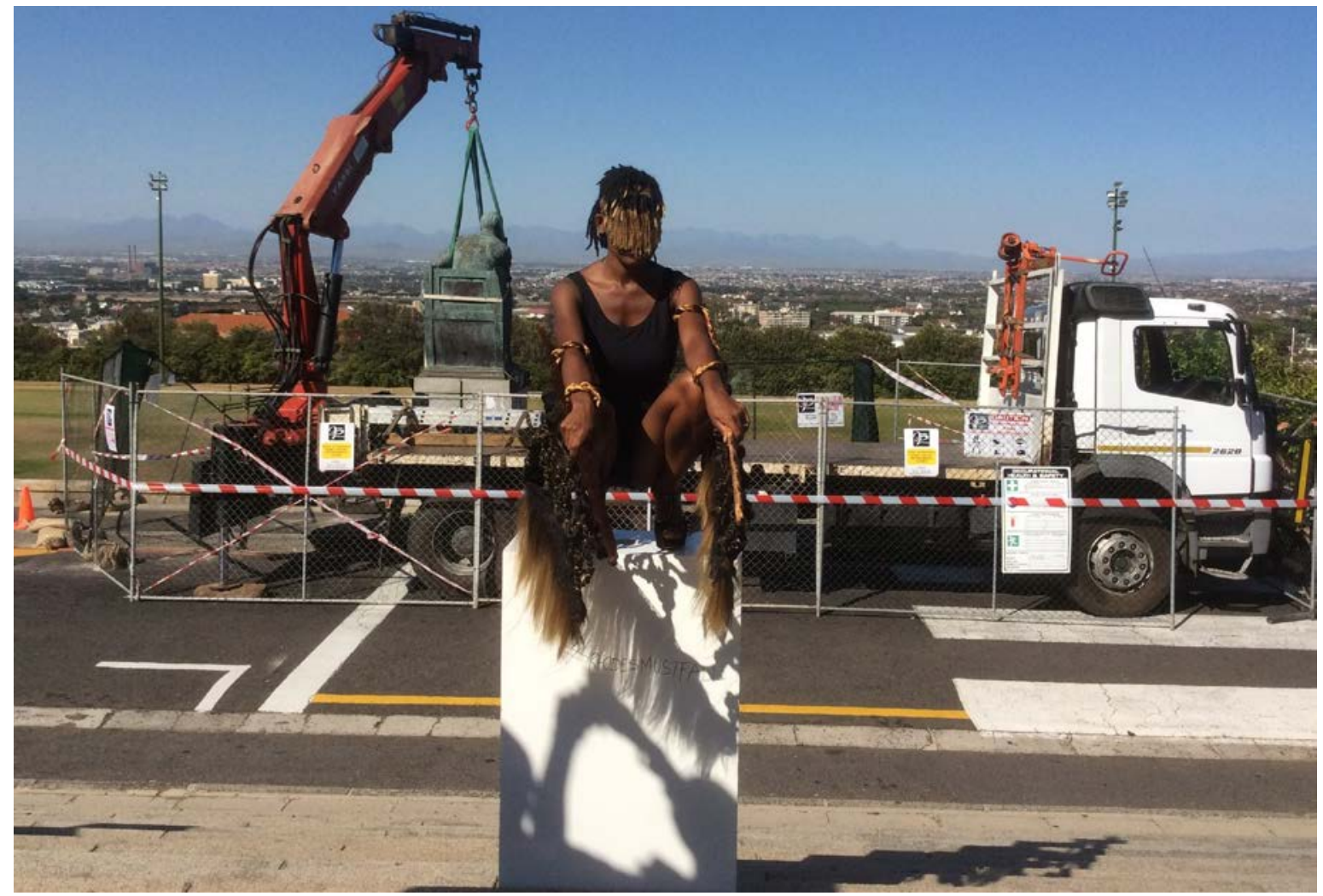

Figure 3: The human statue of Sethembile Msezane with the bronze statue of Cecil Rhodes in the background

We can see her black skin, her eyes covered and feathered wings attached to her arms. She has positioned her art installation courageously facing the campus, the buildings, the people and poignantly all the socio-economic, political and ethical problems that are the result of the deep inequalities exacerbated by apartheid capitalism. Resisting the hierarchies of difference that are 
manifested (also) in South African institutions, Msezane's body is turned with her back towards the Rhodes statue. In contrast, Cecil Rhodes's body slightly leaning forward is turned away from the campus regally looking down, while letting his pensive gaze extend beyond the Cape Flats with its enforced relocated inhabitants, townships and informal settlements towards the North-East as though to map the route of his colonial dream - the Cape-to-Cairo railway.

Msezane's human statue is discursively and materially entangled with the Rhodes statue, as well as the crane that is about to remove it, the truck and the people around it. Her statue has meaning, because of the mutual relationality: things 'are' because they are in relation to and influencing each other. The statues are intra-acting, that is, nature and culture, nonhuman and human exist interdependently, they are ontologically ('onto' means being) always in relation and affected by each other. The entanglement of all human and non-human phenomena intraacting with one another means that it is impossible to say where the boundaries are of each person, or the crane, or the truck, or the camera that was used to take the photo (not only from an epistemological, but also from an ontological point of view). There is no relationship of exteriority between observer and observed, so as the photographer I am just as much part of the phenomena ('exteriority-within-phenomena') - an alternative ontology for the possibility of objectivity (Barad 2007, 140). An obvious objection might be to say that this is just a matter of how humans experience the world subjectively, and not how things are in the world? The way Barad (2007, 155-156) counters this possible objection is worth quoting at length:

At first glance, the outside boundary of a body may seem evident, indeed incontrovertible. A coffee mug ends at its outside surface just as surely as people end at their skins. On the face of it, reliance on visual clues seems to constitute a solid empirical approach, but are faces and solids really what they seem? ... physics tells us that edges or boundaries are not determinate either ontologically or visually. When it comes to the 'interface' between a coffee mug and a hand, it is not that there are $\mathrm{x}$ number of atoms that belong to a hand and $\mathrm{y}$ number of atoms that belong to the coffee mug.

So for Barad the production of bodily boundaries is not a matter of someone's individual, subjective experiences, or about how we know the world, but the way the world is put together ontologically, the way the world is. Barad is not just making the point that it is an empirical fact that there are 'clear boundaries' only for the human eye (therefore subjective), and that this not the case from a physical optics point of view. If we apply this posthumanist perspective to the reading of Figure 3, it could be said that Msezane's 'wings' are part of her body. We use all kinds of objects (e.g. sticks, cell phones, tablets, cameras) as part of our body and in a particular way as the 'result of the repetition of (culturally and historically) specific bodily performance' (Barad 2007, 155). It is only when an object gets lost or stolen - our cell phone, for example that we notice that the phone is an apparatus that is part of an on-going negotiation with the 
world with an image of “"normal embodiment” in mind' (Barad 2007, 158). It is only then that the integral entanglement of the material and the discursive gets noticed (which does not mean that in reality this is not always the case).

Similarly, the complex assemblage of the material and the discursive in Figure 3 also includes me as the person who took the photo. The different elements do not stand in 'a relationship of externality to each other' (Barad 2007, 152). I am not at a distance as a knower 'outside' or 'external' to the intra-actions. Similarly, neither am I now at a distance from the act of re-membering this event 'in' the past. As Barad re-minds us in an interview (Juelskjaer and Schwennesen 2012, 22) 'all the "re's"' as in re-membering 'must be taken as questions, not answers'. The ethical responsibility is for how we constitute entangled relationships. These phenomena are not 'found' or 'discovered', but they are 'data hotspots', that is, 'pieces of data “experienced" ... as intensities of body as well as mind - a kind of glow ... [which] would continue to develop' (MacLure 2013a,173).

I was and still am fully implicated; and that is part of the material and discursive practice. I took the photo sub/consciously with the machines in the background, because of my interest in critical posthumanism. What pulled me to take the photo was the flesh of her gracious body and her beautiful young black skin in the context of the statue's imminent violent removal by the machines in the background. Affect, as Brian Massumi (2015, ix) explains, is '.. prototypical. It concerns the first stirrings of the political, flush with the felt intensities of life.' These concepts are 'transversal', that is, they cut across the usual power producing binaries of the objective and the subjective - they 'stir the mind' as well as 'strike the body' (Massumi 2015, $\mathrm{x})$. They constrain, as well as express desire and freedom.

It struck me how her flesh stood out against the background of the machines that were about to remove the other body made of old bronze just behind her on the left with such brute force. These (never pure) perceptions express themselves in the embodied act of what is better expressed as making the photo, then taking it. The latter would suggest that I positioned myself as a distanced observer using my tablet as a mere tool, but photos are material and discursive constructions. I cannot analyse the event itself as if it were an objective moment in time separate from my own subjectivity (mark making). The photo was inspired by my lived experiences of hierarchies of difference supported by the binaries of humanism: young/old, white/black, real/appearance, male/female, art/science. Donna Haraway (1988) reminds us that binaries reinforce hierarchical thinking, since each part of the binary otherises the other in fixed positions. Msezane's youth, race and gender stand in stark contrast with the older, white, male Cecil Rhodes. It is this juxtaposition that provokes a response, to take response-ability for the 
a/effects of power producing binaries and the marks they make on bodies.

Now why does a posthumanist reading of the photo matter? What difference does it make?

\section{THE POWER OF OBJECTS}

For critical posthumanists, things (matter) are dynamic and have agency (see also: Bennett 2010; Braidotti 2013; Coole and Frost 2010; Hekman 2010; Jackson and Mazzei 2012). Not only Chumani Maxwele’s human excrement, or Sethembile Msezane’s statue have (and still have) agency, the statue of Cecil Rhodes also has, although it is strange to think in terms of power and agency in the context of objects. The inclusion of 'nonhuman agency' marks a radical philosophical departure from poststructuralist invocations of performativity (Barad 2007, 411Fn18) or other linguistic constructionist approaches such as postmodernism. Susan Hekman $(2010,3)$ argues how deeply imbedded linguistic constructionism is in academia, and that, although this philosophical orientation resists dichotomies and binaries (and in that sense posthumanism can be seen as a continuation), the key dichotomy between language (in the broad sense) and reality has been kept firmly in place by 'moving to the language side to the exclusion of reality'. The crucial difference is how posthumanism rejects this dichotomy and formulates a new relationship 'between' language and reality, the ontology of a philosophy of immanence inspired by Spinoza's monism - an orientation that focuses on the performative agency of language, concepts, questions and so forth, and not what language refers to in the real world of so-called inert and passive objects.

Barad finds her philosophical grounding for the idea that agency is an enactment (Barad 2007,235 ) in a particular reading of quantum physics. Statues, whether constructed from flesh or bronze, have 'performative agency' as opposed to the humanist or liberal reading of agency as something or someone has as an independently existing body in space and time. In this public space on the university campus the statues are dynamic, have a 'force and power to transform our thinking and being' (Lenz Taguchi 2010,4) and are therefore educative - even when they have been removed. Matter, Barad $(2007,136)$ writes, is an 'active participant in the world's becoming'. In an interview, Barad (Juelskjaer and Schwennesen 2012, 21) points at the resilience of the animate/inanimate dualism 'that stops animacy cold in its tracks, leaving rocks, molecules, particles, and other inorganic entities on the side of those who are denied even the ability to die, despite the fact that particles have finite lifetimes'. There is a sense in which each molecule and particle that makes up the Rhodes statue remembers what has happened to it, that is, 'the' statue has a memory of its iterative materialisations (Barad in Juelskjaer and Schwennesen 2012, 21). Humans decide who and what matters, and who and what has the 
ability to die. Accepting that the material in our lives also has power and agency, and realising that bodies (including our own) always intra-act with the discursive, can open up a space for a notion of justice, that includes, but goes beyond, social justice. It includes the force of the material, or what Jane Bennett (2010) calls ‘thing-power', the fact that objects (such as statues) command attention and provoke affect.

\section{DIFFRACTION AS A METHODOLOGY}

Although referred to in the literature as a methodology it would be a mistake to regard diffraction as just another tool to be used by humans 'on' the world. Barad $(2007,74)$ uses the term 'diffraction' from physics to describe how 'simply stated, diffraction has to do with the way waves combine when they overlap and the apparent bending and spreading of waves that occurs when waves encounter an obstruction'. Diffraction is not a humanist method of thinking about the world, but expresses the philosophical insight that humans are part of world that is inherently diffractive. Diffraction means ‘to break apart in different directions’ (Barad 2014, 168).

My unfolding analysis of the photo is diffractive and not reflective or reflexive. As opposed to reflection or reflexivity, diffraction looks for diffraction patterns, for 'differencesin-the-making', not sameness (as in mirroring). Re-turning to my analysis, what the diffractive methodology adds to the reading of this 'event', is the inclusion of the materiality of the bodies: the fleshy human black female body as well as the hard white man's body eternalised in bronze. It is tempting to concentrate on the human body - typically positioned by me right in the middle of the photo, but posthumanism 'marks a refusal to take the distinction between "human" and “nonhuman” for granted’ (Barad 2007, 32). In an interview, Msezane describes how standing there for four hours made her legs hurt, her arms sore, her feet blue and her skin sunburnt (Buist 2015). Reading the interview on my tablet, I feel admiration and compassion for her extraordinary commitment to the \#Rhodesmustfall cause. The entanglement of the two statues and other bodies, such as my tablet, the audience, the crane and the truck, continue to leave deep marks on my bodymind. The bronze statue is a powerful sculpture made by Marian Wallgate - one of the few women ever commissioned to sculpt a public monument, and its extraordinary colour, texture and fine detail have power and agency. I do not want the statue to die.

What has struck me is that all discourses surrounding this significant historical event ignore the power of the object itself, its dynamism, its vitality and aesthetic force. The statue's forced and violent removal is legitimised in socio-economic and especially political terms, but 
these discourses ignore the fact that humans are part of the world and not at a distance from it ontologically. Therefore, the social and geo-political perspectives are only part of the entangled phenomenon. So what is left out, forgotten or ignored by using the discursive apparatus of the social sciences only?

My own embodied experience of the statue's pending removal by crane and truck was deeply discomforting. I could not bear to watch the event itself - in the same way I would struggle to witness the demolition of a house, the uprooting of a tree, the eating of the flesh of a nonhuman animal or the execution of a human animal. Through a humanist lens the discomfort can be explained as an expression of white privilege or even guilt - e.g. from a postcolonial, poststructural lens focusing on power, identity and human agency. But I was (also) deeply troubled about the destruction, violence and ugliness towards an aesthetic material object. I started to wonder what these popular theoretical lenses from the social sciences left out. Could it explain my disturbance?

Barad's understanding of quantum physics is an example of reading the natural and social sciences diffractively through one another as the title of her ground breaking book Meeting the Universe Halfway (2007) so poignantly expresses. In her agential realism, I find a philosophical explanation for my dislocated emotions in addition to the hegemonic psychological and psychoanalytical discourses. A body is seen not as a property or entity, but as a field or force, and such an orientation troubles all distinct identity theories as will become clearer below. Identitarianism is deeply humanist with politically left wing as well as right wing adherents. My reading of the photo disrupts this prevailing anthropocentrism that dominates discussions about transformation, also in 'post'colonial South Africa. The ironically western humanist metaphysics that is assumed in these efforts to decolonise higher education threatens to divide our communities even further, because of the binary lenses that are used when constructing and teaching knowledges (even when they are embodied or indigenous knowledges).

Our knowledge about the statues, both Msezane's performative stand-in as well as the original bronze, is indeterminate, because of the very nature of the world that we as observers are also part of. Note that indeterminacy is not the same as uncertainty, which is an epistemic principle. Barad's significant contribution to both physics and philosophy is to see the ontological implications of what Haraway and Bohr before her thought were mainly epistemological issues. Bohr's famous two-slit diffraction experiment (Barad 2007, 81-84) made evident that under certain conditions light behaves like a particle (as Newton thought) and under other conditions it behaves like a wave. Wave and particle are not inherent attributes of objects, but, 'the nature of the observed phenomenon changes with corresponding changes in the apparatus' that measures it 
(Barad 2007, 106). Knowledge is constructed through 'direct material engagement with the world' and not by 'standing at a distance and representing' the world (Barad 2007, 49). The ontology of entities emerges through their relationality depending on the apparatus that measures them (Barad 2007).

Concepts for a critical posthumanist have meaning 'by virtue of their embodiment in the physical arrangement of the apparatus' (Barad 2007, 117; my emphasis). Me, my tablet, the statues, the crane, the truck - we are all what Barad $(2007,148)$ calls apparatuses, that is, 'the material conditions of possibility and impossibility of mattering; they enact what matters and what is excluded from mattering'. They are open-ended practices without intrinsic boundaries, and not 'passive instruments for observations', but part of the ongoing intra-activity of the world (Petersen 2014, 33). In other words, the apparatuses are 'physical arrangements' and produce the phenomena, 'real physical entities of beings' (Barad 2007, 129); the meanings do not exist prior to the making of the photo. It is the material and discursive relationships that bring the meanings into existence, not the other way round.

\section{THE DANGER OF HUMANIST CONCEPTUALISATIONS OF TRANSFORMATION}

In the aftermath of the statue's removal there is much debate and theorising about decolonising a higher education institution such as UCT. The \#Rhodesmustfall movement has brought about an unprecedented amount of discussion and positive action related to transformation, including the reconstitution of selection committees for promotions, a rethinking of the curriculum (e.g. prescribed readings), the renaming of roads and buildings and the removal of other physical and symbolic signs of colonialism on campus. Mbembe (2015) points out, that decolonisation is currently often understood as a psychic state, and not so much a political project. The risk involved in the current focus of transformation in 'post'colonial South Africa on identity and cultural/ethnic/racial differences is that it could fuel the hatred, anger and violence across differences with the targeting of individuals on the basis of their appearance ('white' skin) and Whiteness (even when they are black, see e.g. Mbembe 2015; Fanon 1952/2008). Mbembe (2000, 2) quite rightly points out that Western philosophy has 'denied the existence of any “self” but its own', but his proposal to recognise the 'body and flesh of the "stranger" as flesh and body just like mine [that is] the idea of a common human nature, a humanity shared with others' is a humanist proposal, because it assumes the nature/culture binary and the nonhuman is not included in the category 'others'. Humanism understands difference in the negative: a difference from 'the' Other in a system of separation and division. An ontological separateness is assumed between identified categories, positions or identities, such as race (Lenz Taguchi 
drawing on Deleuze 2012, 269). See, for example, Figure 4. A black student (I presume) objects to the Student Representative Council's claim that they represent other black students. S/he writes: ‘I am black and this “campaign” DOES NOT REPRESENT ME!!’.



Figure 4: A black student has written: 'I am black and this "campaign” DOES NOT REPRESENT ME!!'

The logic of representation assumes a humanist ontology and epistemology, 'where words “refer” to entities as if they were separate and distinct from one another' (MacLure 2013b, 661). For example, the first question that comes to (our habits of) mind is to ask 'what does the human statue mean?'. In an interview Msezane explains her use of wings in her art installation (Buist 2015). They depict, she says, Rhodes’ wrongful appropriation of the statue of the Zimbabwe bird, the national emblem of Zimbabwe, which is still part of his Groote Schuur estate. In the absence of black female bodies in public places she decided to show much of her skin, and she comments (Buist 2015; my emphasis):

I'm not sure that we need statues at all - it's a colonialist thing, like marking territory. My work is a response, to get people to look at the landscape with a different eye. People haven't forgiven or forgotten, they're still harbouring hatred. That's why the statue needed to fall. It fostered the kind of thinking that is dangerous to a country in healing.

To speculate about what made her do it, is indeed tempting. The artist herself wants people to look and to think differently. What would be involved in knowing this human statue? How would one teach 'it', for example, in the university classroom? Imagine bringing in the photo (Figure 3) for a small group discussion with students. What would be the difference between a 
humanist and a posthumanist reading of the photo?

\section{HUMANIST AND POSTHUMANIST READINGS OF THE PHOTO}

In a humanist reading of the photo, Msezane, as the subject of the photograph, is separated and detached from the Cecil Rhodes statue and from the students and staff watching, including me with my tablet 'taking' photos to be analysed. The crane and the truck are merely the backdrop, so the reading of the image relies on a subject/object binary divide. The girl is active and the material world around her is passive. As a subject she acts out her intentions and competencies (Hultman and Lenz Taguchi 2010, 527). The material in the photo is merely the backdrop to what really matters, that is, the symbolic meaning of the human art installation. Physical objects are discrete, clearly separated, in a causal relationship with other objects and 'acting only when acted upon by an external agent' (Jackson and Mazzei 2012, 111). From an educational point of view, teaching students about the statue would involve focusing on the discursive and what the statue means (its historical, geo-political significance). It could also focus on her emotions and what is going on 'inside' her. For example, her anger. What motivated her to do it?

Our entire educational system is built around a logic of representation (e.g. definitions of concepts). This logic positions the human as the only knower and as the constructor of meaning through language and discourses. It is hard to resist a humanist analysis of the human statue (or the photo for that matter) and wonder what the statue represents or symbolises, from a semiotic point of view, and to also focus on her and what she is feeling and thinking. The challenge is to offer students opportunities to alternative nonhuman centred readings using a critical posthumanist orientation, for example, with the help of the diffractive methodology developed by Donna Haraway (1992) as interpreted by Barad (2003; 2007). One can explore the photo's performative agency of the two statues, and ask 'what does it do?' and 'how does it work?', not 'what does it mean?'. Asking for (representational) meaning is a kind of (humanist) knowing that keeps the knower at a distance (through language). Posthuman knowing comes from a direct material engagement with the world (Barad 2007, 49; italics in the original), not at a distance from it through language and shifts the focus on descriptions of reality to matters of practices, doings and actions (Barad 2007, 135).

Swedish teacher educator Lenz Taguchi $(2010,98)$ points out that moving away from anthropocentric thinking in data analysis takes account of time-space-place relations (disrupting 'pre', 'current' and 'post' as linear). To disrupt a humanist, anthropocentric perspective a 'dissolved conception of time' is required, and an egalitarian 'flattened' reading of the data in order to do justice to the 'thickness of corporeality and materiality in the event' (Lenz Taguchi 
2010, 98-99). The idea of 'flattened' (horizontal) as opposed to hierarchical (vertical) comes from John Frown (Hultman and Lenz Taguchi 2010, 529).

In this particular context a moving away from a privileged human perspective could involve asking the students to document both statues from the perspective of the nonhuman, e.g. the sounds of the crane, the smell of the spilled diesel of the truck, the texture of the ropes around the statue, the chirping sounds of the birds, the shine of the bronze, the beating of Msezane's heart, the tickling sensation of the wings' feathers and so forth. The human and nonhuman bodies are doing something to 'each other'. They transform as an effect of the intraactions that emerge 'between' them. The bronze statue offers certain possibilities to the human statue and the other way around. For example, Rhodes' position facing away from UCT affords Msezane to position hers towards the campus and face the audience. The human and the nonhuman statue, the camera, the students watching and the photographer (me) are all are overlapping forces: the cold bronze, its aged colour, Msezane's still body and silence, the steps, the force of gravity, her sweat, the plinth, her 'wings', her rumbling tummy. Neither has agency on its own and new meanings materialise as an effect of their mutual engagement and quantum entanglement. There are no stable identities, but a continuous becoming of bodies that transform as an effect of the intra-actions that (e)merge 'between' them. The material has agency in what is said and done and how the photo works. The pull of the material to have the photo made. Cameras are usually regarded as subordinate to humans' agency, that is, without 'intention, agency, vibrancy or force that isn't triggered by humans of attributable to their actions' (Allen 2015, 13). In critical posthumanism the human and non-human are understood as performative agents making themselves known to each other (Lenz Taguchi 2010).

Reading the photo in this way would only actualise 'one of a multiplicity of aspects in the many folds of the thick mixture which makes up the learning event' (Lenz Taguchi 2010, 98). The statues and their entangled relationships are part of the complex mix of causal intra-actions that would make students think and feel differently about the 'event' as an unpredictable, dynamic material-discursive process. A posthuman framework opens up new ways of thinking about how texts, such as visual images, can be read with students, and changes how we enact the binary categories embedded in everyday language, especially the language/reality dichotomy.

\section{QUEERING HUMANIST SUBJECTIVITY}

The current focus on identity and cultural/ethnic/racial differences tends to be understood in the negative: a difference from 'the' Other in a system of separation and division. Barad (2007, 
134) describes this 'I' of humanism as a 'distinct individual, the unit of all measure, finitude made flesh, his separateness is the key’. Lenz Taguchi $(2010,57)$ points out that for Deleuze and Guattari everything in our thinking flows from the habit of saying ' $\mathrm{I}$ '. The self is named and cut apart from other selves and things. The not ' $\mathrm{I}$ ' is in opposition, different from the ' $\mathrm{I}$ ' that has not only been cut apart from other animals and things, but an 'I' that has also been put above nonhuman others celebrating a higher ontological status. This ' $\mathrm{I}$ ' is normative and also includes or excludes the other 'I's - a distancing or cutting apart from the 'other' human that is not 'fully' formed or developed (as yet) - the 'I' who is 'disabled', 'female', 'child', 'black', 'poor'.

The posthuman subject does not pre-exist in its relationships with others, but materialises in intra-action (Barad 2012, 77). Subjectivity as quantum entanglement includes the excluded and marginalised of humanism?1: 'the sexualized other (woman), the racialized other (the native) and the naturalized other (animals, the environment, or earth)' (Braidotti 2013, 27). What is needed to 'overcome' humanism is not another theory, but a proposal to live without bodily 'borders' or 'boundaries' - the indeterminate subject is not a 'new' unity, but like 'a' sea that troubles the very nature of one-ness, two-ness, three-ness ... the use of the pronoun should provoke 'a different sense of a-count-ability, a different arithmetic, a different calculus of response-ability’ (Barad 2014, 178).

Like Barad, Braidotti also proposes an indeterminate subject that is 'nomadic' without one singular stable identity or being firmly located geographically, historically, ethnically, or fixed by a particular class structure, but a subject that is continuously 'becoming' - a corporeal entity that has spatio-temporal force, embedded and embodied, and therefore immanent and dynamic (Braidotti 2006, 151-152; Braidotti 2013). The key idea here is that self is not 'subject-assubstance', but always 'subject-in-process', and always produced involving contradiction (and diffractions). Therefore, the answer to what it means to decolonise will always be new, and continuously disrupt the power producing binaries of humanist discourses. We cannot abandon these binaries, because they have become part of the fabric of who we are through western ontology and epistemology. They are entrenched in the language we enact, think with and have shaped our hierarchical 'long-term memory (family, race, society, or civilisation) [that] traces and translates, but what it translates continues to act in it, from a distance, off beat, in an “untimely” way, not instantaneously’ (Deleuze and Guattari 1987/2014, 16). For decolonisation it is essential that there is no separating into differences (e.g. black/white), but being creative by offering new beginnings - what Barad (2014) refers to as a 'cutting-together-apart' - an ontological, epistemological and ethico-political project, that does not limit the pain, suffering 
and grief currently expressed by the \#Rhodesmustfall movement to the psychic realm.

Diffraction as a methodology troubles notions such as identity and difference and queers (as opposed to 'normal' or 'natural') binaries (Barad 2014, 171). Diffraction breaks through the tyranny of thinking in terms of identity that cuts us apart from other earth dwellers (a concept that includes matter) - it sees difference as difference between two or more entities. But in the same way that electrons are neither just wave, nor particle, but both, I am also both male and female, nature and culture, white and black. These differences are not ignored or erased by thinking and being in this way, but seen as relations of 'difference within' (Barad 2014, 175) a 'material multiplicity of self'. Differences are not 'givens' (attached to a person), but are formed through intra-activity in the making of 'this' or 'that' within the phenomenon that is constituted in the entanglement (e.g. a photo). Importantly, entanglements are not unities, because each bit of matter, each position in space, at each moment of time, is not 'a blending of separate parts or a blurring of boundaries, but in the thick web of its specificities, what is at issue is its unique material historialities and how they come to matter' (Barad 2014, 176).

A philosophy of immanence sees difference as difference without identity, that is, a difference that assumes being without substance and subject, 'the establishment of a relationality that is affirmative - structured by positivity rather than negativity’ (Dolphijn and Van der Tuin 2012, 127). The active, creative process of 'pushing dualisms to the extreme' (Dolphijn and Van der Tuin 2012, 127) also pushes difference to the limit, and instead of looking for the same in the other (e.g. black, young, able, female) it involves looking for difference in the other, which is not evaluative, but performative (Dolphijn and Van der Tuin 2012, 127).

More than two millennia of western metaphysical thought has shaped this binary language we think with - a language that has been too 'substantialising', bringing into existence figurations of the human as substance with essence, as if the subject-predicate structure of language reflects an ontology: the independently existing human with, for example, competencies, attributes, agency and voice (Deleuze and Guattari, 1987/2014). Language has been granted excessive power in determining what is real, and has instilled a deep mistrust of matter, figuring it as mute, passive, immutable (Barad 2007, 133). Language and discourse have positioned us, human animals, as thinkers above or outside the (material) world, and with that same move have distanced us, 'fully-human' adults, from both matter and other earth dwellers, including objects; and by regarding them as inert and passive we do not acknowledge how objects can a/effect our bodies. Rejecting the possibility that one can feel sorry for a statue that is about to be violently removed by a crane, because it could be argued it has been infused with 
colonial baggage, amounts to valuing the discursive more over the material. This prioritisation would deny the ontological fact that they are always entangled, and fails to acknowledge the power of the object and the marks 'it' can leave on one's body that is always multiple (Deleuze and Guattari, 1987/2014). Causal intra-actions do not need to involve humans (Barad 2007, 140).

\section{SITUATED KNOWLEDGE}

The core challenge for the \#Rhodesmustfall movement and the decolonisation of higher education is not to focus on negative differences (black/white, male/female), but to disrupt the language/reality dichotomy 'left' in place by humanism, and to contest the engrained humanist belief that humans' claimed unique ability to reason through language places them above, and 'gives them control' over, animals, plants, and their physical environment. The metaphysics of humanism cannot be left behind and replaced by something new. There is no salvation or a proposal for the 'death of metaphysics' (Barad 2007, 136). Cartesian dualism has given rise to a notion of objectivity that assumes that it is possible to re-present the world through knowledge systems and to claim that knowledge is not embodied with a knowing subject whose eyes represent, while escaping representation, and who, with a god's eye, gaze from nowhere in particular (Haraway 1988, 581). Importantly, it is assumed that there is no direct access to reality; humans are kept at a distance from what things are, and this includes what 'race' is. Moving away from this humanist representationism, Barad has read the insights of poststructuralism, science studies and quantum physics diffractively through one another to arrive at the insight that the relationship between nature and culture is not one of absolute exteriority as humanism suggests, but a dynamic relation of ‘exteriority within' (Barad 2007, 135).

The theorising of what it means to decolonise higher education should therefore also include an enquiry into the notion of 'situated knowledges' as it is often used to defend cultural, moral and epistemic relativism and the inclusion of indigenous knowledge systems in higher education curricula. For Barad (2007, 470), the concept 'position' is not stable and 'location' is not about a 'fixed position'. She rightly points out how Donna Haraway's notion of 'situated' has been profoundly misunderstood, that is, conflated 'with the specification of one's social location along a set of axes referencing one’s identity' (Barad 2007, 470Fn45). For example, an email address is specific in the internet, but this net itself is always fluid and becoming, and so are identities (Barad 2007, 470Fn45). For Barad location is about 'specific connectivity' (Barad 2007, 471Fn45) and has to do with how non-dualist subjects intra-act with the world. 
We have seen in this article how matter and meaning are intricately entangled as a matter of fact. And so is the indeterminate position and location of the subject. Her radical contestation of western ontology opens up possibilities of thinking about decolonisation differently. Like an atom, people's identities are not given, never stable or fixed and always open to future and past reworkings, including the possibility of changing the past (Barad, 2007). Quantum physics disrupts the idea of linear time continuity, and has provided empirical evidence that identity is performed, not fixed and depends on the apparatus that measures it. The analysis of my photo of the two statues together (Figure 3) has paid careful attention to how me/my camera as an apparatus has brought into existence the material force of human and nonhuman bodies 'in' the photo which are never 'pure', natural or biological, but a complex interplay of highly constructed social, affective and material symbolic forces (Braidotti 2002, 21).

Due to its particular history, South Africa has a different trajectory from other northern and southern contexts regarding issues of social justice and social inclusion (Mbembe 2015). Here, white oppressors preserved their socioeconomic privileges after 1994, despite being in the minority. Furthermore, even within South Africa, the differently positioned historically advantaged and disadvantaged institutions, which have been inherited from the apartheid era, present particular challenges for justice and inclusion, especially for a historically white university such as UCT.

\section{A MATTER OF JUSTICE}

An alternative positive philosophical orientation towards a 'post'colonial future sees difference as always (e)merging as an a/effect of connections and relations within and between bodies. Critical posthumanism profoundly democratises relationships within the one species (e.g. young/old, black/white, male/female) and between humans and other earth dwellers. Nothing is regarded as standing 'outside', 'above', or taking a true privileged transcendental position. The decolonising difference this makes is that humans are normally not viewed relationally and as always already entangled with nonhuman others. This leads to complexity and reduction in diversity, does not respect otherness, and thereby misses important knowledges. The act of representing is an act of mediation between knower and known, that displays for Barad 'a deep mistrust of matter, holding it off at a distance’ (Barad 2007, 133).

A key tenet of this article has been my argument that discussions about transformation often do not acknowledge the entanglement of the ontological and the epistemological. Accepting that the material in our lives also has power and agency, and realising that bodies (including our own) always intra-act with the discursive, makes room for empathy and care for the nonhuman 
other, including the statue of Rhodes. The power and agency of this object is not limited to its symbolic meaning. The world of meaning is more than what can be represented in human-made language, otherwise the world would be precisely what gets lost (Barad 2007, 137). The removal of language (in the broad sense) as the only knowledge-producing tool allows the material world 'in' when making sense of one's own affect when statues are forcibly removed or houses demolished. Crucially it leaves open the question of what it means to decolonise a university.

\section{NOTE}

1. I have introduced the neologism 'iii' to express linguistically a subject that is 'bodymindmatter' (Murris 2016, especially Chapter 4).

\section{REFERENCES}

Allen, L. 2015. The power of things! A 'new' ontology of sexuality at school. Sexualities. Published first on-line: 10.1177/1363460714550920.

Barad, K. 2003. Posthumanist performativity: Toward an understanding of how matter comes to matter. Signs: Journal of Women in Culture and Society 28(31): 801-831.

Barad, K. 2007. Meeting the universe halfway: Quantum Physics and the entanglement of matter and meaning. Durham: Duke University Press.

Barad, K. 2012. 'Intra-actions’: An interview with Karen Barad by Adam Kleinman. Mousse \#34 June: 76-81.

Barad, K. 2014. Diffracting diffraction: Cutting together-apart. Parallax 20(3): 168-187.

Bennett, J. 2010. Vibrant matter: A political ecology of things. Durham \& London: Duke University Press.

Braidotti, R. 2002. Metamorphoses: Towards a materialist theory of becoming. Oxford: Blackwell Publishers.

Braidotti, R. 2006. Transpositions: On nomadic ethics. Cambridge: Polity Press.

Braidotti, R. 2013. The posthuman. Cambridge: Polity Press.

Buist, E. 2015. Sethembile Msezane performs at the fall of the Cecil Rhodes statue, 9 April 2015. The Guardian, May 19. http//:www.theguardian.com.

Coole, D. and S. Frost, eds. 2010. New materialisms: Ontology, agency, and politics. Durham, Duke University Press.

Deleuze, G. and F. Guattari. 1987/2014. A thousand plateaus. Translated and a foreword by B. Massumi. London: Bloomsbury.

Dolphijn, R. and I. van der Tuin. 2012. New materialism: Interviews \& cartographies. Open Humanities Press. http://openhumanitiespress.org

Fanon, F. 1952/2008. Black skin, white masks. Translated by C. L. Markmann. London: Pluto Press.

Fleisch, B. 2008. Primary education in crisis: Why South African schoolchildren underachieve in reading and mathematics. Cape Town: Juta.

Haraway, D. 1988. Situated knowledges: The Science question in feminism and the privilege of partial perspective. Feminist Studies 14: 575-599.

Haraway, D. 1992. The promises of monsters: A regenerative politics for inappropriate/d others. In Cultural studies, ed. L. Grossberg, C. Nelson and P. A. Treichler, 295-337. New York: Routledge. 
Hekman, S. 2010. The material of knowledge: Feminist disclosures. Bloomington: Indiana University Press.

Hultman, K. and H. Lenz Taguchi. 2010. Challenging anthropocentric analysis of visual data: A relational materialist methodological approach to educational research. International Journal of Qualitative Studies in Education 23(5): 525-542.

Jackson, A. Y. and L. A. Mazzei. 2012. Thinking with theory in qualitative research: Viewing data across multiple perspectives. New York: Routledge.

Juelskjaer, M. and N. Schwennesen. 2012. Intra-active entanglements - an interview with Karen Barad. Kvinder, Kon-Forskning Nr 1-2.

Lenz Taguchi, H. 2010. Going beyond the theory/practice divide in early childhood education. London: Routledge Contesting Early Childhood Series.

Lenz Taguchi, H. 2012. A diffractive and Deleuzian approach to analysing interview data. Feminist Theory 13(3): 265-281.

MacLure, M. 2013a. Classification or wonder? Coding as an analytic practice in qualitative research. In Deleuze and research methodologies, ed. R. Coleman and J. Ringrose, 164-183. Edinburgh: Edinburgh University Press.

MacLure, M. 2013b. Researching without representation? Language and materiality in post-qualitative methodology. Special Issue: Post-Qualitative Research. International Journal of Qualitative Studies in Education 26(6): 658-667.

Massumi, B. 2015. Politics of affect. Cambridge: Polity Press.

Mbembe, A. 2000/2015. On the postcolony. Johannesburg: Wits University Press.

Mbembe, A. 2015. Achille Mbembe on the state of South African political life. Africa as a country. September 19. http//www.africasacountry.com.

Morreira, S. 2015. Steps towards decolonial higher education in South Africa? Epistemic disobedience in the humanities. Journal of Asian and African Studies. Published on-line. $10.1177 / 0021909615577499$

Murris, K. 2016. The posthuman child: Educational transformation through philosophy with picturebooks. London: Routledge Contesting Early Childhood Series.

Petersen, K. S. 2014. Interviews as intraviews: A hand puppet approach to studying processes of inclusion and exclusion among children in kindergarten. Reconceptualising Educational Research Methodology 5(1): 32-45.

Van der Berg, S., S. Taylor, M. Gustafsson, N. Spaull and P. Armstrong. 2011. Improving education quality in South Africa. Report for the National Planning Commission September 2011. Department of Economics, University of Stellenbosch. http://resep.sun.ac.za

Zembylas, M. 2007. Mobilising anger for social justice: The politicization of the emotions in education. Teaching Education 18(1): 15-28.

Zembylas, M. and S. Chubbuck. 2009. Emotions and social inequalities: Mobilizing emotions for social justice education. In Advances in teacher emotion research: The impact on teachers' lives, ed. P. Schutz and M. Zembylas, 343-363. Springer: Dordrecht, The Netherlands. 